\title{
Synergistic effect of bladder cancer-specific oncolytic adenovirus in combination with chemotherapy
}

\author{
SHUWEN LI ${ }^{1 *}$, FANG WANG $^{2 *}$, ZHENXING ZHAI $^{1}$, SHENGJUN FU $^{1}$, JIANZHONG LU $^{1}$, HONGJUAN ZHANG ${ }^{1}$, \\ HONGYU GUO ${ }^{1}$, XUEMEI HU ${ }^{1}$, RENJU LI ${ }^{1}$, ZHIPING WANG ${ }^{1}$ and RONALD RODRIGUEZ ${ }^{3}$ \\ ${ }^{1}$ Urologic Clinical Center of Gansu Province, Key Laboratory of Gansu Province, Institute of Urology, \\ The Second Hospital of Lanzhou University, Lanzhou, Gansu 730030; ${ }^{2}$ Medical Experiment Center, \\ School of Basic Medical Sciences, Lanzhou University, Lanzhou, Gansu 730000, P.R. China; ${ }^{3}$ Department of Urology, \\ University of Texas Health Science Center at San Antonio, San Antonio, TX 78229, USA
}

Received October 21, 2015; Accepted April 13, 2017

DOI: $10.3892 / \mathrm{ol} .2017 .6416$

\begin{abstract}
Gene therapy with adenoviral early region gene (E1A) may enhance the susceptibility of neoplastic cells to chemotherapy-induced cell death. Our previous study developed a urothelium-specific oncolytic serotype 5 adenovirus (Ad5) with the uroplakin II (UPII) promoter controlling E1A expression. The present study investigated whether this urothelium-specific recombinant adenovirus (Ad5-UPII-E1A) enhanced mitomycin (MMC) and hydroxycamptothecin (HCPT) sensitization and drug-induced apoptosis in bladder cancer cells. The results of the MTT assay revealed that combination therapy, using Ad5-UPII-E1A and MMC or HCPT, synergistically inhibited the viability of bladder cancer cells in a dose- and time-dependent manner when compared with either agent alone. When cells were treated with Ad5-UPII-E1A alone they arrested in the G1 phase, but cell cycle analysis by flow cytometry revealed $\mathrm{S}$ phase arrest when treated with combined therapy. Treatment with MMC or HCPT enhanced Ad5-UPII-E1A-induced apoptosis in 5,637 cells, observed by transmission electron microscopy. Western blot analysis revealed that MMC and HCPT enhanced the E1A expression of the Ad5-UPII-E1A vectorin a dose-dependent manner. The present study demonstrated
\end{abstract}

Correspondence to: Dr Zhiping Wang, Urologic Clinical Center of Gansu Province, Key Laboratory of Gansu Province, Institute of Urology, The Second Hospital of Lanzhou University, 82 Cui Ying Men, Lanzhou, Gansu 730030, P.R. China

E-mail:erywzp@lzu.edu.cn

Dr Ronald Rodriguez, Department of Urology, University of Texas Health Science Center at San Antonio, 7703 Floyd Curl Drive, San Antonio, TX 78229, USA

E-mail: rodriguezr32@uthscsa.edu

${ }^{*}$ Contributed equally

Key words: oncolytic adenovirus, chemotherapy, mitomycin, hydroxycamptothecin that Ad5-UPII-E1A combined with MMC or HCPT resulted in synergistic cytotoxicity in a process which involved the promotion of apoptosis in bladder cancer cell lines. MMC and HCPT also promoted the oncolytic effect of Ad5-UPII-E1A. Thus, treatment using Ad5-UPII-E1A combined with MMC or HCPT may be an attractive strategy for the sensitization of bladder cancer to chemotherapy.

\section{Introduction}

Bladder cancer is one of the most prevalent types of cancer globally (1), with recurrence rates as high as $67 \%$ in the first 12 months following treatment (2). A substantial proportion (16-25\%) of urothelial cancers are invasive, infiltrating high-grade carcinomas which will progress to metastasis (3), resulting in a poor 5-year survival rate.

Intravesical chemotherapy effectively reduces and delays tumor recurrence and progression (3). Drugs available at present for this purpose include thiotepa, Adriamycin, epirubicin, doxorubicin (DOX) and mitomycin C (MMC) (4). MMC has a wide spectrum of antitumor activity $(5,6)$. Hydroxycamptothecin (HCPT) has a significant effect on the proliferation and apoptosis of human bladder cancer and prostate cancer cell lines in vitro $(7,8)$. HCPT has previously been demonstrated to have a marked effect on cell cycle progression by forcing the cells into $S$ arrest (9). However, due to the presence of cancer stem cells in invasive bladder cancer, the majority of bladder cancer cells demonstrate chemoresistance (10). Therefore, it is essential to identify an effective chemosensitizer and multimodal strategy to treat invasive bladder cancer.

Adenovirus, which is a well-characterized system with deficient replication, has been widely used in cancer gene therapy studies, including bladder cancer (11-14). Our previous study constructed urothelium-specific recombinant adenovirus type 5 [Ad5-UPII-adenoviral early region gene (E1A)] with E1A (541 bp) and uroplakin II promoter (UPII promoter, $314 \mathrm{bp}$ ), which promoted the expression of the E1A gene and limited replication of adenovirus to urothelial cells (15). Our previous studies demonstrated that the oncolytic Ad5-UPII-E1 A had a bladder cancer cell-specific antitumor effect in vivo and in vitro (14-16). Oncolytic adenovirus also 
functions as a chemosensitizer for different antitumor mechanisms $(17,18)$. However, little is known about the anticancer effect of oncolytic Ad5-UPII-E1A combined with MMC or HCPT.

Therefore, in the present study, the oncolytic Ad5-UPII-E1A adenovirus was combined with MMC or HCPT to investigate whether there was a synergistic inhibitory effect on bladder cancer cell viability, and to screen for potential mechanisms.

\section{Materials and methods}

Adenovirus vectors and cell lines. Urothelium-specific recombinant Ad5-UPII-E1A was constructed with uroplakin II promoters driving expression of the E1A gene of adenovirus serotype 5. Handling, replication, amplification, purification and titration of Ad5-UPII-E1A were performed as previously described (14). Our previous studies revealed that Ad5-UPII-E1A with 10 multiplicity of infection (MOI) had the most significant cytotoxicity within $96 \mathrm{~h}$ (16), therefore, all human bladder cancer cells were infected with Ad5-UPII-E1A at a MOI of 10 in the present study.

Human bladder cancer 5,637 cells were obtained from the American Type Culture Collection (Manassas, VA, USA) and maintained in RPMI-1640 medium supplemented with $10 \%$ fetal bovine serum (both from Thermo Fisher Scientific, Inc., Waltham, MA, USA), $100 \mathrm{U} / \mathrm{ml}$ penicillin and $100 \mathrm{U} / \mathrm{ml}$ streptomycin at $37^{\circ} \mathrm{C}$ in $5 \% \mathrm{CO}_{2}$.

Chemotherapeutic agents. MMC and HCPT (Sigma-Aldrich; Merck KGaA, Darmstadt, Germany) were prepared as a stock solution at concentrations of 0.4 and $1.0 \mathrm{mg} / \mathrm{ml}$, frozen in sterile $1.5 \mathrm{ml}$ tubes individually at $-80^{\circ} \mathrm{C}$, protected from light and used only once. The stock solutions were serially diluted prior to their addition to cell cultures to reach final concentrations of $0.05,0.1$ and $0.2 \mathrm{mg} / \mathrm{ml} \mathrm{MMC} \mathrm{and} \mathrm{0.1,0.2}$ and $0.4 \mathrm{mg} / \mathrm{ml} \mathrm{HCPT}$. Chemotherapy drugs were added $4 \mathrm{~h}$ following the infection with Ad5-UPII-E1A.

Cell viability assay. Cell viability was quantified by MTT assay. Bladder cancer 5,637 cells in 96-well plates at $2 \times 10^{3}$ cells per well were infected with Ad5-UPII-E1A, chemotherapy drugs MMC and HCPT, or infected by Ad5-UPII-E1A combined with either single agent. Mock-treated cells (treated with equal amounts of PBS) without any treatment were used as negative controls. Following treatment for $24,48,72$ or $96 \mathrm{~h}$ at $37^{\circ} \mathrm{C}$, respectively, the medium was replaced with $90 \mu \mathrm{l}$ serum-free medium and $10 \mu \mathrm{l} \mathrm{MTT} \mathrm{solution} \mathrm{(5} \mathrm{mg} / \mathrm{ml}$ in sterile PBS). Following incubation for $4 \mathrm{~h}$ at $37^{\circ} \mathrm{C}$, the MTT solution in the wells was replaced with $150 \mu \mathrm{l}$ dimethyl sulfoxide. The absorbance of the samples was measured using a Bioelisa Reader (EXL-800, BioTek Instruments, Inc., Winooski, VT, USA) at $490 \mathrm{~nm}$. The percentage of cell viability was calculated according to the formula $100 \%$ x (mean value A490 of infected cells)/(mean value A490 of uninfected cells). Results are expressed as the mean \pm standard deviation (mean \pm SD) for selected paradigms performed in triplicate $(n=3)$. The nature of the combined effect of drugs with adenovirus was estimated by using previously published methods (19). In brief, the expected value of combination effect between treatment 1 and treatment 2 was calculated as [(observed treatment 1 value)/(control value) $]$ x [(observed treatment 2 value)/(control value)] $\mathrm{x}$ (control value), and the combination index was calculated as the ratio of (expected value)/(observed value). A ratio of $>1$ indicated a synergistic effect, and a ratio of $<1$ indicated an antagonistic effect.

Cell cycle distribution analysis. A total of 5,637 cells ( $3 \times 10^{6}$ cells/culture flask) was treated with Ad5-UPII-E1A alone or combined with different concentrations of MMC $(0.05,0.1$ and $0.2 \mathrm{mg} / \mathrm{ml})$ or HCPT $(0.1,0.2$ and $0.4 \mathrm{mg} / \mathrm{ml})$ for 48,72 and $96 \mathrm{~h}$ at $37^{\circ} \mathrm{C}$ and was harvested using trypsin. The cells were washed with PBS and then kept overnight at $4^{\circ} \mathrm{C}$ in $70 \%$ ethanol. The cells were then collected and resuspended in PBS, propidium iodide (PI; $50 \mathrm{mg} / \mathrm{ml}$; Sigma-Aldrich; Merck KGaA) and RNase A (100 mg/ml; Thermo Fisher Scientific, Inc.), and incubated at $37^{\circ} \mathrm{C}$ for $30 \mathrm{~min}$. Cell cycle distribution was evaluated by flow cytometry (Beckman Coulter Epics XL; Beckman Coulter, Inc., Brea, CA, USA), and data were analyzed by CytExpert software (edition 1.0.135.1; Beckman Coulter, Inc., Brea, CA, USA).

Apoptosis assays. Annexin V and PI double dyes and immunofluorescence flow cytometry assay were used to examine the apoptotic rate of the 5,637 cell line following treatment with Ad5-UPII-E1A alone or combined with different concentrations of MMC $(0.05,0.1$ and $0.2 \mathrm{mg} / \mathrm{ml})$ and $\mathrm{HCPT}(0.1,0.2$ and $0.4 \mathrm{mg} / \mathrm{ml})$. After $72 \mathrm{~h}$ treatment with adenovirus and chemotherapy, 5,637 cells $\left(1 \times 10^{6}\right)$ were collected and resuspended in binding buffer (Wuhan Amyjet Scientific, Inc., Wuhan, China), Annexin V-fluorescein isothiocyanate (FITC) and PI (Vybrant Apoptosis Assay kit 2; Molecular Probes; Thermo Fisher Scientific, Inc.) were added to each sample according to the manufacturer's instructions and incubated in the dark for $10 \mathrm{~min}$ at room temperature. The number of apoptotic cells was evaluated by flow cytometry $(E x=488 \mathrm{~nm} ; \mathrm{Em}=530 \mathrm{~nm}$; BD Biosciences, San Jose, CA, USA), and data were analyzed by CytExpert software (edition 1.0.135.1; Beckman Coulter, Inc.).

Electron microscopy assay. For ultrastructural analyses, 5,637 cells were treated with Ad5-UPII-E1A and/or drugs and incubated for $72 \mathrm{~h}$. The cells were washed with PBS, suspended in $2.5 \%$ glutaraldehyde, post-fixed for $1 \mathrm{~h}$ in $1 \%$ osmium tetroxide at room temperature, dehydrated in ethanol $(15,30,50,70$ and 90\%), and embedded in epoxy resin (at room temperature for $12 \mathrm{~h}$ ). Ultrathin sections were cut (10-mm thick), stained with lead citrate and uranyl acetate (for $15 \mathrm{~min}$ at room temperature) and observed with JEM-1230 transmission electron microscopy (TEM; Japan; magnification, $\mathrm{x} 3,000-40,000)$.

Western blot analysis for E1A expression. To detect expression of the E1A gene and virus replication in cells, 5,637 cells were infected with recombinant Ad5-UPII-E1A at an MOI=10 only, or followed by combined treatment with MMC or HCPT. After $72 \mathrm{~h}$, cells were washed with PBS and then lysed in radioimmunoprecipitation assay cell lysis buffer with the fresh protease inhibitor phenylmethylsulfonyl fluoride (Sigma-Aldrich; Merck $\mathrm{KGaA})$ on ice. Total protein $(40 \mu \mathrm{g})$ was separated on $8-12 \%$ polyacrylamide gels and then transferred to polyvinylidene 

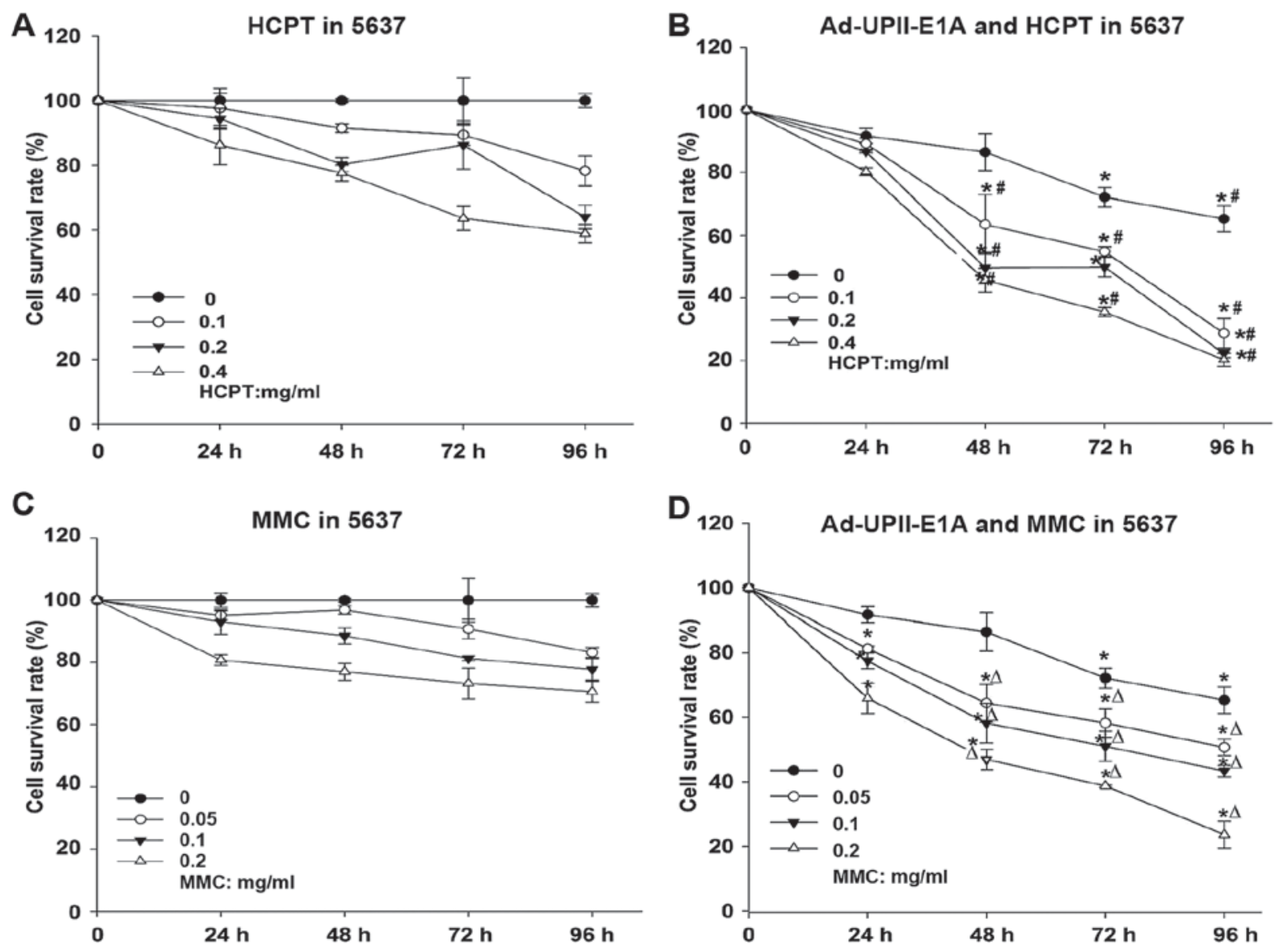

Figure 1. Ad5-UPII-E1A combined with MMC or HCPT synergistically inhibits cell growth in a dose and time-dependent manner. Bladder cancer 5,637 cells treated with an increasing dose of (A) HCPT or (C) MMC and Ad5-UPII-E1A (10 multiplicity of infection) (B and D) were determined by MTT assay. Data are presented as the mean \pm standard deviation of three independent experiments. ${ }^{*} \mathrm{P}<0.05$ vs. Ad5-UPII-E1A group, ${ }^{~} \mathrm{P}<0.05$ vs. $\mathrm{HCPT}$ alone group, ${ }^{\Delta} \mathrm{P}<0.05$ vs. MMC alone group. Ad5-UPII-E1A, urothelium-specific recombinant adenovirus type 5; MMC, mitomycin; HCPT, hydroxycamptothecin.

fluoride membranes $(0.22 \mu \mathrm{m})$. The membranes were incubated with anti-Ad5 E1A mouse mono-clonal antibodies at a dilution of 1:200 (cat. no. ab52523; Abcam, Cambridge, UK) at $4^{\circ} \mathrm{C}$ overnight. Horseradish peroxidase-conjugated anti-mouse immunoglobulin G (cat. no. TA130005, OriGene Technologies, Inc., Beijing, China) was used as a secondary antibody at a dilution of 1:500 at room temperature for $2 \mathrm{~h}$. Reactivity was visualized using an enhanced chemiluminescence system (Upstate Biotechnology, Inc., Lake Placid, NY, USA). Equal amounts of protein loading were controlled by GAPDH in the sample and visualized with mouse anti-GAPDH mAb (cat. no. TA802519; OriGene Technologies, Inc.) at a dilution of 1:1,000 at $4^{\circ} \mathrm{C}$ overnight.

Statistical analysis. Data are presented as the mean \pm SD. All experiments were performed in triplicate. Statistical analysis was conducted using SPSS software (version 17.0; SPSS, Inc., Chicago, IL, USA). Significance was assessed using one-way analysis of variance and a post hoc test (Tukey's test). $\mathrm{P}<0.05$ was considered to indicate a statistically significant difference.

\section{Results}

MMC and HCPT combined with Ad5-UPII-E1A synergistically inhibits cell viability yin a dose-and time-dependent manner. To evaluate the cytotoxic effects of the combination treatment, the viability of the human bladder cancer 5,673 cell line was depicted by a dose-response curve (Fig. 1). MTT assays were performed according to a standard operating procedure. Drug concentration was optimized to a certain extent so that it would not generate an extensive cytotoxic effect alone. Dose ranges of the MMC $(0.05,0.1$ and $0.2 \mathrm{mg} / \mathrm{ml})$ and HCPT $(0.1,0.2$ and $0.4 \mathrm{mg} / \mathrm{ml})$, as well as 10 MOI Ad5-UPII-E1A were used. The nature of the combined effect of drugs with adenovirus was estimated as described in material and methods. Therefore, compared with either chemotherapy drug alone (Fig. 1A and C), MMC and HCPT combined with Ad5-UPII-E1A synergistically inhibited cell growth in a doseand time-dependent manner in bladder cancer 5,637 cells (Fig. 1B and D).

A total of 5,637 bladder cancer cells is arrested at the G1 or $S$ phase when treated with adenovirus or combination therapy. In order to decipher the suppressive mechanisms of Ad5-UPII-E1A and MMC and HCPT on bladder cancer cells, the changes of cell cycle distribution were monitored using flow cytometry. Compared with the control group, when 5,637 cells were infected with Ad5-UPII-E1A (10 MOI) for 48, 72 and $96 \mathrm{~h}$, the proportions of G0/G1 phase cells were $92.85 \pm 1.4,83.39 \pm 2.31$ and $80.8 \pm 1.83 \%$, respectively, and the proportion of $\mathrm{S}$ phase cells did not exceed $20 \%$ in these groups (Fig. 2A). Cell cycle was arrested in the G1 phase. However, in 

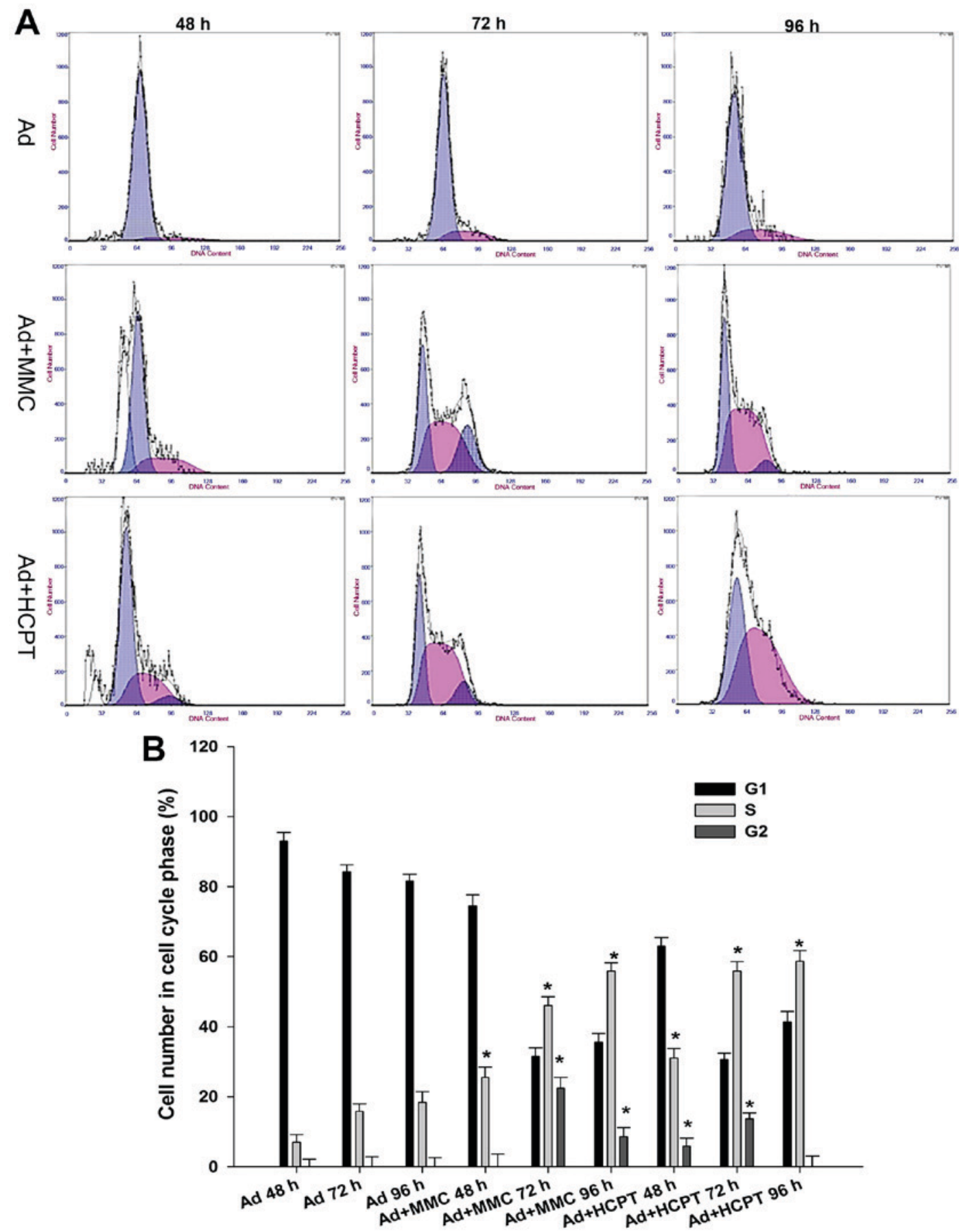

Figure 2. Cell cycle analysis of bladder cancer cells treated with oncolytic Ad5-UPII-E1A, or with Ad5-UPII-E1A and MMC or HCPT. (A) A total of 5,637 cells treated with Ad5-UPII-E1A alone, Ad5-UPII-E1A combined with MMC or combined with HCPT for 48, 72 and 96 h. (B) Quantification of the cell cycle analysis results. Data are presented as the mean \pm standard deviation of three independent experiments. " P $<0.05$ vs. Ad5-UPII-E1A alone group. Ad5-UPII-E1A, urothelium-specific recombinant adenovirus type 5; MMC, mitomycin; HCPT, hydroxycamptothecin.

the combination group, following treatment of 5,637 cells with $0.1 \mathrm{mg} / \mathrm{ml}$ MMC or HCPT combined with Ad5-UPII-E1A (10 MOI), the proportion of $\mathrm{S}$ phase cells increased with time, and the proportion of G2/M phase cells decreased with time (Fig. 2A). Cell cycle was arrested in the $\mathrm{S}$ phase. When 5,637 cells were treated with $0.1 \mathrm{mg} / \mathrm{ml} \mathrm{MMC} \mathrm{combined} \mathrm{with}$ Ad5-UPII-E1A (10 MOI) for $72 \mathrm{~h}$, the proportion of cells in the $\mathrm{S}$ phase increased along with time, and the proportion of G2/M phase cells decreased to $22.4 \pm 1.32 \%$ (Fig. 2A). When 5,637 cells were treated with two chemotherapy drugs at a concentration of $0.1 \mathrm{mg} / \mathrm{ml}$ combined with Ad5-UPII-E1A, the cell cycle was blocked at the $\mathrm{S}$ phase (Fig. 2A). The difference of cell proportion in the $\mathrm{S}$ phase between the combined group and the Ad5-UPII-E1A group was significant $(\mathrm{P}<0.01$; Fig. 2B).

Chemotherapy enhances Ad5-UPII-E1A-induced necrosis in 5,637 cells. To investigate whether the adenovirus and chemotherapy-mediated cell death in bladder cancer cells was due to an apoptotic mechanism, apoptosis was analyzed by flow cytometry with FITC and PI double staining. In cell scatter plots, there were almost no apoptotic cells in the control 
A
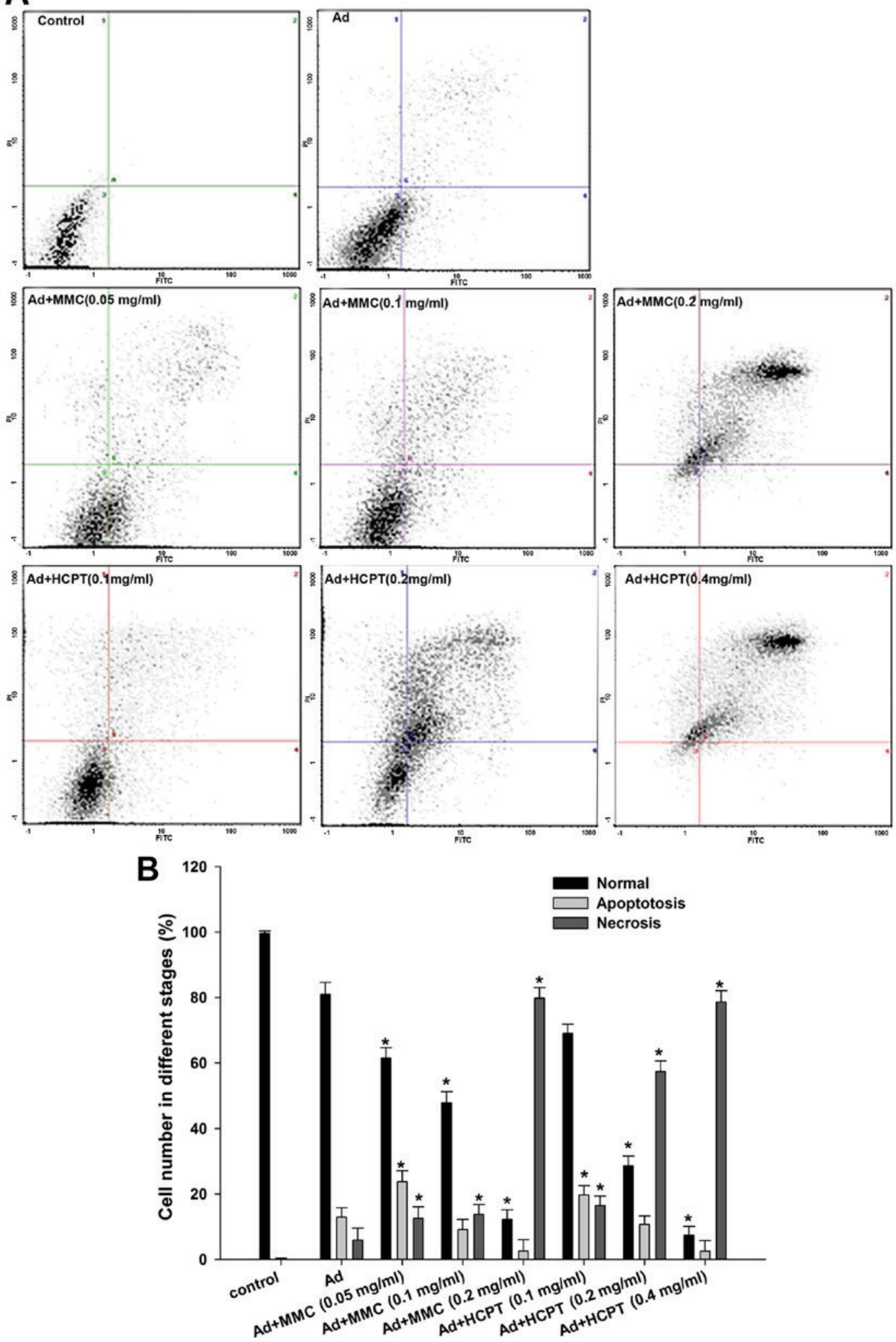

Figure 3. Chemotherapeutic agents enhance Ad5-UPII-E1A-induced necrosis in 5,637 cells. (A) Apoptosis (lower right quadrant) and necrosis (upper right quadrant) detection of the 5,637 cell line treated with Ad5-UPII-E1A and different doses of MMC and HCPT for $72 \mathrm{~h}$. (B) Quantification of apoptosis and necrosis. "P<0.05 vs. Ad5-UPII-E1A alone group. MMC, mitomycin; HCPT, hydroxycamptothecin; Ad5-UPII-E1A, urothelium-specific recombinant adenovirus type 5 .

group, and normal cells accounted for $99.6 \%$ of all cells (Fig. 3A). The apoptotic rate was $12.93 \%$ in 5,637 cells when treated with Ad5-UPII-E1A alone for $72 \mathrm{~h}$ (Fig. 3A). However, when 5,637 cells were treated with Ad5-UPII-E1A combined with MMC, the apoptotic rate was $23.8(0.05 \mathrm{mg} / \mathrm{ml}), 9.13$ $(0.1 \mathrm{mg} / \mathrm{ml})$ and $2.6 \%(0.2 \mathrm{mg} / \mathrm{ml}$; P $<0.05$; Fig. 3A, the lower right quadrant), while the proportion of necrotic cells gradually increased by $12.6,13.8$ and $79.8 \%$, respectively $(\mathrm{P}<0.05$; 


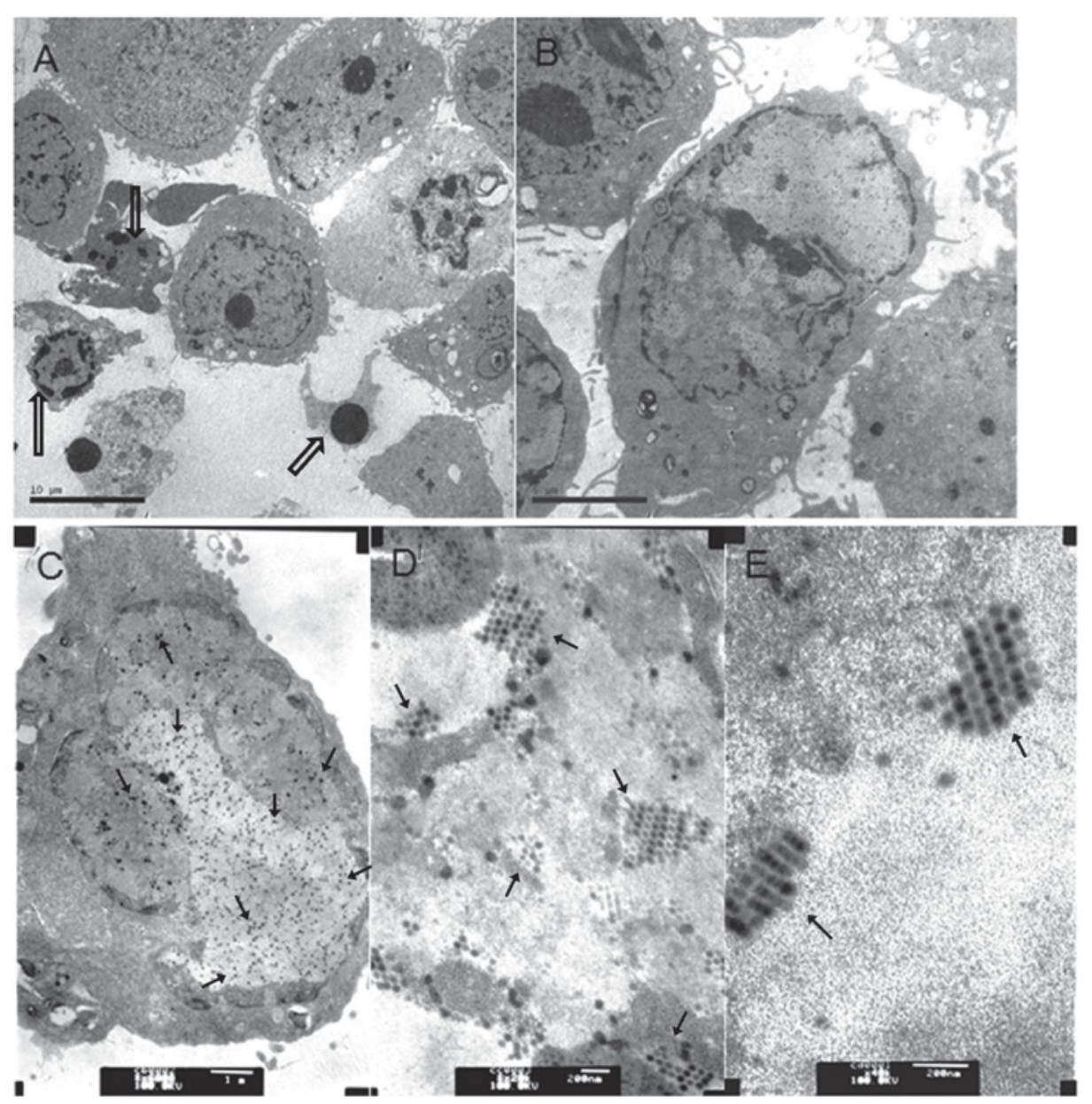

Figure 4. Virus particles in bladder cancer cells infected with Ad5-UPII-E1A or Ad5-UPII-E1 Acombined with MMC or HCPT. (A) A total of 5,637 cells was treated with $0.4 \mathrm{mg} / \mathrm{ml} \mathrm{HCPT}$ and Ad5-UPII-E1A (10 MOI) for $72 \mathrm{~h}$ (magnification, $\mathrm{x} 3,000$ ). (B) A total of 5,637 cells was treated with $0.2 \mathrm{mg} / \mathrm{ml} \mathrm{MMC}$ combined with Ad5-UPII-E1A (10 MOI) for $72 \mathrm{~h}$ (magnification, x6,000). (C) A total of 5,637 cells was treated with Ad5-UPII-E1A alone, and the uniform distribution of virus particles within the cell is visible (magnification, $\mathrm{x} 20,000)$. (D) Distribution of virus particles within the cell (magnification, $\mathrm{x} 40,000$ ), (E) Virus particle morphology (magnification, $\mathrm{x} 40,000$ ). Hollow arrows indicate the fragmented nuclei, the gathering of nuclearchromatin and the formation of apoptotic bodies. Regular arrows indicate the virus particles. Ad5-UPII-E1A, urothelium-specific recombinant adenovirus type 5; MMC, mitomycin; HCPT, hydroxycamptothecin; $10 \mathrm{MOI}, 10$ multiplicity of infection.

Fig. 3A, the upper right quadrant). This indicated that a low dose of chemotherapy combined with Ad5-UPII-E1A induced an apoptotic effect, while a high dose of chemotherapy combined with Ad5-UPII-E1A induced necrosis in a dose-dependent manner. The apoptotic and necrotic trends of the HCPT combined with Ad5-UPII-E1A groups were similar, but the apoptosis and necrosis effect were more evident compared with MMC (Fig. 3A). For instance, when comparing the two drugs at the same concentrations of $0.1 \mathrm{mg} / \mathrm{ml}, 9.13 \%$ of cells were apoptotic following treatment with MMC combined with Ad5-UPII-E1A, and $13.8 \%$ of cells were necrotic (Fig. 3A). However, in the HCPT combined with Ad5-UPII-E1A group, $19.73 \%$ of cells were apoptotic and $16.5 \%$ were necrotic (Fig. 3A). The quantification of the results is depicted in Fig. 3B.

Apoptosis was most notable in the HCPT combined with Ad5-UPII-E1A group by TEM. To analyze whether chemo drugs MMC and HCPT combined with Ad5-UPII-E1A promoted apoptosis, TEM was used to capture images of 5,637 cells following treatment with Ad5-UPII-E1A and drugs for 72 h. As shown in Fig. 4, virus particles were observed in cells from the two combined groups (Fig. 4A and B) and Ad5-UPII-E1A group (Fig. 4C). The distribution and quantity of virus particles was not visibly different. Recombinant adenovirus was widely present in the cytoplasm, either scattered or regularly spaced (Fig. 4D and E). The early apoptotic phenotype, including vacuolization, cell shrinkage and the advanced apoptotic phenotype of budding and edge set, and the apoptosis bodies, were all observed in cells of the combined groups (Fig. 4A and B). The phenomenon of apoptosis was most notable in the group treated with HCPT combined with Ad5-UPII-E1A for $72 \mathrm{~h}$, and apoptosis occurred in a time-dependent manner (Fig. 4A).

Ad5-UPII-E1A expresses higher levels of E1A protein following exposure to MMC and HCPT. For Ad5-UPII-E1A, the E1A expression vector contains the entire E1A coding sequence under the regulation of the UPII promoter (16). To assess whether the expression of Ad5-UPII-E1A vector was increased following treatment with MMC or HCPT, expression of E1A protein from infected 5,637 cells was examined using western blot analysis. As shown in Fig. 5, when 5,637 cells were treated by Ad5-UPII-E1A (10 MOI) combined with 


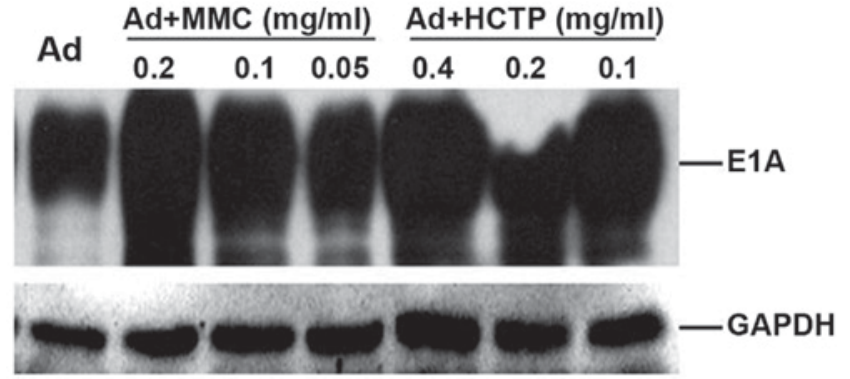

Figure 5. Expression of E1A in the 5,637 cell line following treatment with MMC or HCPT. A total of 5,637 cells was infected with recombinant Ad5-UPII-E1A (10 MOI) alone or with Ad5-UPII-E1A combined with MMC or HCPT for $72 \mathrm{~h}$. The results revealed that, following exposure to Ad5-UPII-E1A (10 MOI) combined with different doses of MMC and HCPT for $72 \mathrm{~h}$, E1A was increased compared with Ad5-UPII-E1A alone, and is increase was dependent on the dose of MMC and HCPT. GAPDH was used as a loading control. E1A, adenoviral early region gene; MMC, mitomycin HCPT, hydroxycamptothecin; Ad5-UPII-E1A, urothelium-specific recombinant adenovirus type 5; $10 \mathrm{MOI}, 10$ multiplicity of infection.

different doses of MMC and HCPT for 72 h, Ad5-UPII-E1A expressed higher levels of E1A protein compared with the Ad5-UPII-E1A alone group. Furthermore, the increase of E1A was dosage-dependent in the Ad5-UPII-E1A and MMC combination group (Fig. 5). Multiple E1A protein species were produced from this vector, as predicted, ranging in size from $\sim 30-50 \mathrm{kDa}$. E1A-hybridizing bands were detected in infected 5,637 cells, thus, Ad5-UPII-E1A was able to effectively transduce 5,637 cells with the addition of chemotherapy drugs, resulting in the production of multiple E1A protein species.

\section{Discussion}

Oncolytic adenoviruses, which are considered to be an important method of cancer gene therapy, have been an effective treatment strategy to date (11). Furthermore, tissue-specific adenovirus may function as a type of tumor-specific chemotherapy sensitizer, since it is highly targeted to tumor tissues through tissue-specific promoters and enhancers (20). It has been reported that the adenovirus E1A gene may induce sensitivity to DNA-damaging agents, including cisplatin (CDDP), DOX and $\gamma$ irradiation on squamous cell carcinoma cells. Ganjavi et al (21) demonstrated that Ad-wtp53 significantly increased sensitivity of the cell lines [Saos-2 (p53-/-), HOS (R156P), KHOS/NP (R156P) and MNNG (R156P, F270L)] to CDDP and DOX, chemotherapeutic agents commonly used in the treatment of osteosarcoma.

The present study revealed that chemotherapy combined with Ad5-UPII-E1A more effectively killed bladder cancer cells than the groups treated with MMC/HCPT or Ad5-UPII-E1A alone, as indicated in Fig. 1. When 5673 cells were treated with HCPT $(0.2 \mathrm{mg} / \mathrm{ml})$ for $96 \mathrm{~h}$, cell viability was $63.98 \%$, however, when 5,673 cells were treated with adenovirus plus HCPT $(0.1 \mathrm{mg} / \mathrm{ml})$ for $48 \mathrm{~h}$, cell viability declined to $63.51 \%$, indicating that pre-treatment of cells with Ad5-UPII-E1A sensitized cells to chemotherapy-induced cell death, and therefore it may be possible to reduce the drug dosage. In combination therapy, reduced dosage of chemotherapy drugs may achieve an improved therapeutic effect, which may alleviate the side effects of chemotherapy drugs. Ad5-UPII-E1A increased the sensitivity of bladder cancer cells to chemotherapy, and E1A protein expression sensitized tumor cells to chemotherapy drugs. One of the molecular mechanisms by which E1A induces chemosensitization is downregulation of erb-b2 receptor tyrosine kinase 2/proto-oncogene Neuoverexpression $(22,23)$. Inhibition of protein kinase Band activation of p38 was reported to provide a general cellular mechanism for E1A-mediated chemo sensitization $(24,25)$. Regulation of certain critical tumor suppressors was also proposed as being involved in E1A-induced chemo sensitization, including p53 and p19 $\mathrm{ARF}(26)$, the pro-apoptotic protein B-cell lymphoma-2-associated $X$ protein, caspase 9 and an as-of-yet unidentified inhibitor that ordinarily provides protection against cell death $(27,28)$. A forkhead box O3 a dependent mechanism of E1A-induced chemo sensitization was also previously reported (29). The mechanisms underlying E1A protein-induced sensitization of bladder cancer cells to HCPT and MMC will be discussed in the near future.

Next, the mechanisms underlying the antitumor effect of the combined treatment were investigated. The cell cycle and apoptosis distribution, determined by flow cytometric analysis, demonstrated that chemotherapy promoted oncolytic adenovirus-induced apoptosis. When bladder cancer cells were treated with Ad5-UPII-E1A alone, the cell cycle was arrested in the G1 phase. However, when cells were treated with Ad5-UPII-E1A and HCPT or MMC, the cell cycle was arrested in the $\mathrm{S}$ phase, demonstrating that the drugs have a stronger cell cycle blocking function than Ad5-UPII-E1A. Pharmacological studies have demonstrated that MMC is able to block the cell cycle at the $\mathrm{G} 1$ and $\mathrm{S}$ phase in the late period (30). HCPT has a cytotoxic activity against $\mathrm{S}$-phase cells (31), which was consistent with the results of the present study.

The fact that theapoptotic effect was increased by combined treatment demonstrated that Ad5-UPII-E1A combined with MMC or HCPT had amore comprehensive inhibitory effect on bladder cancer cells. Greater apoptosis and necrosis effects were observed in the combination therapy group under an electron microscope. The observation of cell phenotypes in the early or late-stage of apoptosis demonstrated that addition of MMC and HCPT enhanced Ad5-UPII-E1A-induced apoptosis. The phenomenon of apoptosis was most notable in the group treated with a combination of HCPT and Ad5-UPII-E1A for $72 \mathrm{~h}$, compared with MMC combined therapy, which may provide a reference for clinical application. The results of the present study were similar to those of other studies that demonstrated the existence of a cooperative or enhanced curative effect when chemotherapy was combined with adenovirus treatment $(32,33)$. The present study confirmed that a combination of chemotherapy with adenovirus resulted in an enhanced antitumor effect through the induction of apoptosis.

By contrast, the effect of MMC and HCPT on Ad5-UPII-E1A was investigated. Compared with the group treated only with Ad5-UPII-E1A, MMC and HCPT promoted adenoviral E1A protein expression. This may be caused by the increased mRNA transcription levels of E1A, and the potential underlying mechanisms will be explored in the future.

Although combination therapy was demonstrated to result in decreased 5,637 cell viability and increased apoptosis, with this increase depending on the dose of MMC and HCPT, the 
underlying mechanisms remain to be reported. Additional studies are required to validate the synergistic effect of Ad5-UPII-E1A and chemotherapy combination treatment on animals and in clinical trials, and to investigate the mechanisms underlying the synergistic sensitization. In conclusion, combined therapy using Ad5-UPII-E1A and MMC or HCPT may be a promising treatment for patients with bladder cancer.

\section{Acknowledgements}

The present study was supported by the National High-Tech R\&D Program of China (863 program; grant no. 2008AA02Z421), the National Natural Science Foundation of China (grant nos. 81172437/H1619 and 81372733/H1619) and the Natural Science Foundation of Gansu Province (grant no. 1506RJZA234).

\section{References}

1. Cheung G, Sahai A, Billia M, Dasgupta P and Khan MS: Recent advances in the diagnosis and treatment of bladder cancer. BMC Med 11: 13, 2013.

2. Sylvester RJ, van der Meijden AP, Oosterlinck W, Witjes JA, Bouffioux C, Denis L, Newling DW and Kurth K: Predicting recurrence and progression in individual patients with stage Ta T1 bladder cancer using EORTC risk tables: A combined analysis of 2596 patients from seven EORTC trials. Eur Urol 49: 466-477, 2006.

3. Voutsinas GE and Stravopodis DJ: Molecular targeting and gene delivery in bladder cancer therapy. J Buon 14 (Suppl 1): 69-78, 2009.

4. Babjuk M, Oosterlinck W, Sylvester R, Kaasinen E, Böhle A and Palou-Redorta J; European Association of Urology (EAU): EAU guidelines on non-muscle-invasive urothelial carcinoma of the bladder. Eur Urol 54: 303-314, 2008.

5. Crooke ST and Bradner WT: Mitomycin C: A review. Cancer Treat Rev 3: 121-139, 1976.

6. Verweij J and Pinedo HM: Mitomycin C: Mechanism of action, usefulness and limitations. Anticancer Drugs 1: 5-13, 1990.

7. Wu Y, Zeng FQ, Wang YB and Wang L: Hydroxycamptothecin promotes the apoptosis of prostate cancer cell line PC-3. Zhonghua Nan KeXue 13: 890-894, 2007 (In Chinese).

8. Fan J, Tang X and Zhang X: 10-Hydroxycamptothecin induces apoptosis in human T24 urinary bladder cancer cells. Zhonghua Yi XueZaZhi 78: 301-304, 1998 (In Chinese).

9. Liu LF, Desai SD, Li TK, Mao Y, Sun M and Sim SP: Mechanism of action of camptothecin. Ann N Y Acad Sci 922: 1-10, 2000.

10. Dean M, Fojo T and Bates S: Tumour stem cells and drug resistance. Nat Rev Cancer 5: 275-284, 2005.

11. Bochner BH: Gene therapy in bladder cancer. Curr Opin Urol 18: 519-23, 2008.

12. Wada Y, Gotoh A, Shirakawa T, Hamada K and Kamidono S: Gene therapy for bladder cancer using adenoviral vector. Mol Urol 5: 47-52, 2001

13. Chester JD, Kennedy W, Hall GD, Selby PJ and Knowles MA: Adenovirus-mediated gene therapy for bladder cancer: Efficient gene delivery to normal and malignant human urothelial cells in vitro and ex vivo. Gene Ther 10: 172-179, 2003.

14. Wang F, Wang Z, Tian H, Qi M, Zhai Z, Li S, Li R, Zhang H, Wang W, Fu S, et al: Biodistribution and safety assessment of bladder cancer specific recombinant oncolytic adenovirus in subcutaneous xenografts tumor model in nude mice. Curr Gene Ther 12: 67-76, 2012.

15. Wang D, Wang Z, Tian J, He X, Chowdhury WH, Zhang X, Li S and Rodriguez R: Prostate stem cell antigen enhancer and uroplakin II promoter based bladder cancer targeted tissue-specific vector. Urol Oncol 28: 164-169, 2010.
16. Zhai Z, Wang Z, Fu S, Lu J, Wang F, Li R, Zhang H, Li S, Hou Z, Wang H and Rodriguez R: Antitumor effects of bladder cancer-specific adenovirus carrying E1A-andro gen receptor in bladder cancer. 19 1065-1074, 2012.

17. Guo W, Zhu H, Zhang L, Davis J, Teraishi F, Roth JA, Stephens C, Fueyo J, Jiang H, Conrad C and Fang B: Combination effect of oncolytic adenovirotherapy and TRAIL gene therapy in syngeneic murine breast cancer models. Cancer GeneTher 13: 82-90, 2006.

18. Alonso MM, Gomez-Manzano C, Jiang H, Bekele NB, Piao Y, Yung WK, Alemany R and Fueyo J: Combination of the oncolytic adenovirus ICOVIR-5 with chemotherapy provides enhanced anti-glioma effect in vivo. Cancer Gene Ther 14: 756-761, 2007.

19. Zhou JR, Yu L, Mai Z and Blackburn GL: Combined inhibition of estrogen-dependent human breast carcinoma by soy and tea bioactive components in mice. Int J Cancer 108: 8-14, 2004.

20. Sánchez-Prieto R, Quintanilla M, Cano A, Leonart ML, Martin P, Anaya A and Ramón y Cajal S: Carcinoma cell lines become sensitive to DNA-damaging agents by the expression of the adenovirus E1A gene. Oncogene 13: 1083-1092, 1996.

21. GanjaviH,Gee M,Narendran A, Parkinson N, Krishnamoorthy M, Freedman MH and Malkin D: Adenovirus-mediated p53 gene therapy in osteosarcoma cell lines: Sensitization to cisplatin and doxorubicin. Cancer Gene Ther 13: 415-419, 2006.

22. Brader KR, Wolf JK, Hung MC, Yu D, Crispens MA, van Golen KL and Price JE: Adenovirus E1A expression enhances the sensitivity of an ovarian cancer cell line to multiple cytotoxic agents through an apoptotic mechanism. Clin Cancer Res 3: 2017-2024, 1997.

23. Ueno NT, Bartholomeusz C, Herrmann JL, Estrov Z, Shao R, Andreeff M, Price J, Paul RW, Anklesaria P, Yu D, Hung MC, et al: E1A-mediated paclitaxel sensitization in HER-2/neu-overexpressing ovarian cancer SKOV3.ip1 through apoptosis involving the caspase-3 pathway. Clin Cancer Res 6: 250-259, 2000.

24. Liao Y and Hung MC: Regulation of the activity of p38 mitogen-activated protein kinase by Akt in cancer and adenoviral protein E1A-mediated sensitization to apoptosis. Mol Cell Biol 23: 6836-6848, 2003.

25. Liao Y and Hung MC: A new role of protein phosphatase $2 \mathrm{a}$ in adenoviral E1A protein-mediated sensitization to anticancer drug-induced apoptosis in human breast cancer cells. Cancer Res 64: 5938-5942, 2004.

26. de Stanchina E, McCurrach ME, Zindy F, Shieh SY, Ferbeyre G, Samuelson AV, Prives C, Roussel MF, Sherr CJ and Lowe SW: E1A signaling to 553 involves the p19(ARF) tumor suppressor. Genes Dev 12: 2434-2442, 1998.

27. Duelli DM and Lazebnik YA: Primary cells suppress oncogene-dependent apoptosis. Nat Cell Biol 2: 859-862, 2000.

28. McCurrach ME, Connor TM, Knudson CM, Korsmeyer SJ and Lowe SW: bax-deficiency promotes drug resistance and oncogenic transformation by attenuating p53-dependent apoptosis. Proc Natl Acad Sci USA 94: 2345-2349, 1997.

29. Su JL, Cheng X, Yamaguchi H, Chang YW, Hou CF, Lee DF, Ko HW, Hua KT, Wang YN, Hsiao M, et al: FOXO3a dependent mechanism of E1A-Induced chemosensitization. Cancer Res 71: 6878-6887, 2011.

30. Olivier M and Theillet C: Mitomycin C induced apoptosis: influence of cell cycle phase. Biology of the Cell 88: 82-82a, 1996.

31. Hu W, Zhang C, Fang Y and Lou C: Anticancer properties of 10 -hydroxycamptothecin in a murine melanoma pulmonary metastasis model in vitro and in vivo. Toxicol In Vitro 25: 513-520, 2011.

32. Tanaka $M$ and Grossman HB: Connexin 26 gene therapy of human bladder cancer: Induction of growth suppression, apoptosis, and synergy with Cisplatin. Hum Gene Ther 12: 2225-2236, 2001.

33. Li Y, Yu DC, Chen Y, Amin P, Zhang H, Nguyen N and Henderson DR: A hepatocellular carcinoma-specific adenovirus variant, CV890, eliminates distant human liver tumors in combination with doxorubicin. Cancer Res 61: 6428-6436, 2001. 